\title{
Variability and correlation of milk urea content with parameters of cow productivity
}

\author{
Anatoly Bolgov ${ }^{1, *}$, Irina Komlyk $^{1}$, and Natalia Grishina ${ }^{1}$ \\ ${ }^{1}$ Petrozavodsk State University, Institute of Biology, Ecology and Agricultural technologies, 185910 Lenin str. 33, Petrozavodsk, \\ Russia
}

\begin{abstract}
During the work, 24774 individual milk samples for Ayrshire cows (Karelia, Russia) with an annual milk yield of over $8.300 \mathrm{~kg}$ were tested (1.355 cows) every month for the last three years. The urea content averaged $32.19 \mathrm{mg} \%$ with a daily yield of $25.5 \mathrm{~kg}$. In cows at the age of the first two lactations, the urea content was higher than for adult animals. The urea content in milk increased from $31.46 \mathrm{mg} \%$ to $33.56 \%$ with increasing daily yield. In summer and early autumn, urea concentration was lower than in spring and winter. A reliable positive correlation of milk urea was obtained with daily yield, lactose, negative - with protein, dry milk matter, dry non-fat milk residue, the number of somatic cells, and lack of connection was with fat and the freezing temperature of milk. The bull's genotype has a significant effect on the amount of milk urea. Heritability coefficient $\left(\mathrm{h}^{2}\right)$ was in the range of $0.222-0.367$.
\end{abstract}

\section{Introduction}

Modern diets for highly productive cow are based on a high level of concentrated feed (up to $65 \%$ by nutritional value) that often causes disturbances in protein metabolism, which leads to lower indicators of productivity, reproduction, health, and premature culling of animals. It was found that the concentration of urea in blood and milk could be an indicator of these changes [1-6].

Urea belongs to non-protein nitrogenous substances, being the main compound in their composition and end product of nitrogenous protein metabolism. Unlike proteins and fats that are synthesized in the lacteous gland urea leaves the blood and passes unchanged into milk.

Literature data on the amount of urea in milk indicate a prominent instability of this indicator. Most authors consider $15-30 \mathrm{mg} \%$ as a physiological norm with a protein content of 3.2-3.6\% [7, 2]. Low and high levels of urea are undesirable. The level of urea in milk below $15 \mathrm{mg} \%$ indicates a deficiency, the level of more than 30 $\mathrm{mg} \%$ means an excess of nitrogen in the rumen. Milk should contain no more than $20 \mathrm{mg} \%$ of urea with an annual milk yield of 8000-12000 kg [8].

Variability in the concentration of urea in milk is due to various physiological, genetic and ecological factors. The influence of these factors and the use of milk urea as an indicator of protein metabolism in animals' organism and dietary balance control require further research $[1,2$, 9].

The aim of this study is to investigate the variability and correlation of urea level in milk with other components depending on various factors during monthly monitoring.

\section{Materials and methods}

The work was carried out at a large breeding plant "Megrega" (The Republic of Karelia, Russia). The herd numbers 1,355 Ayrshire cows. The cows are kept in a year-round loose housing without pasture. The share of concentrated feed by nutritional value averaged $57 \%$ in the structure of the annual diet. The average milk yield of cows per lactation was $8300 \mathrm{~kg}$ of milk.

The content of urea and other indicators of the composition and properties of milk was determined in 24,774 milk samples taken according to the results of monthly control milking of cows for 3 years. Milk was analyzed in a specialized laboratory by infrared spectrometry method using "Bentley Combi FTS-500" equipment. In addition to milk urea (MU), the authors took into account the daily milk yield (DY), the mass fraction of fat (MF), protein (MP), lactose, dry milk matter, dry non-fat milk residue, the number of somatic cells and the freezing temperature of milk. The age of cows, daily and lactation milk yield, stage of lactation, month and season of the year and bull genotype were taken into account as variability factors of milk urea, fat and protein in milk.

A histogram was built to assess the distribution of cows by the concentration of milk urea. While testing the hypothesis of normal distribution, we proceeded from the fact, that it obeys the normal law if the arithmetic mean ( ), median (Me), and mode (Mo) are the same or close in magnitude. The coefficients of asymmetry (As) and kurtosis (Ex) were also determined. Methods of

\footnotetext{
* Corresponding author: bolg@petrsu.ru
} 


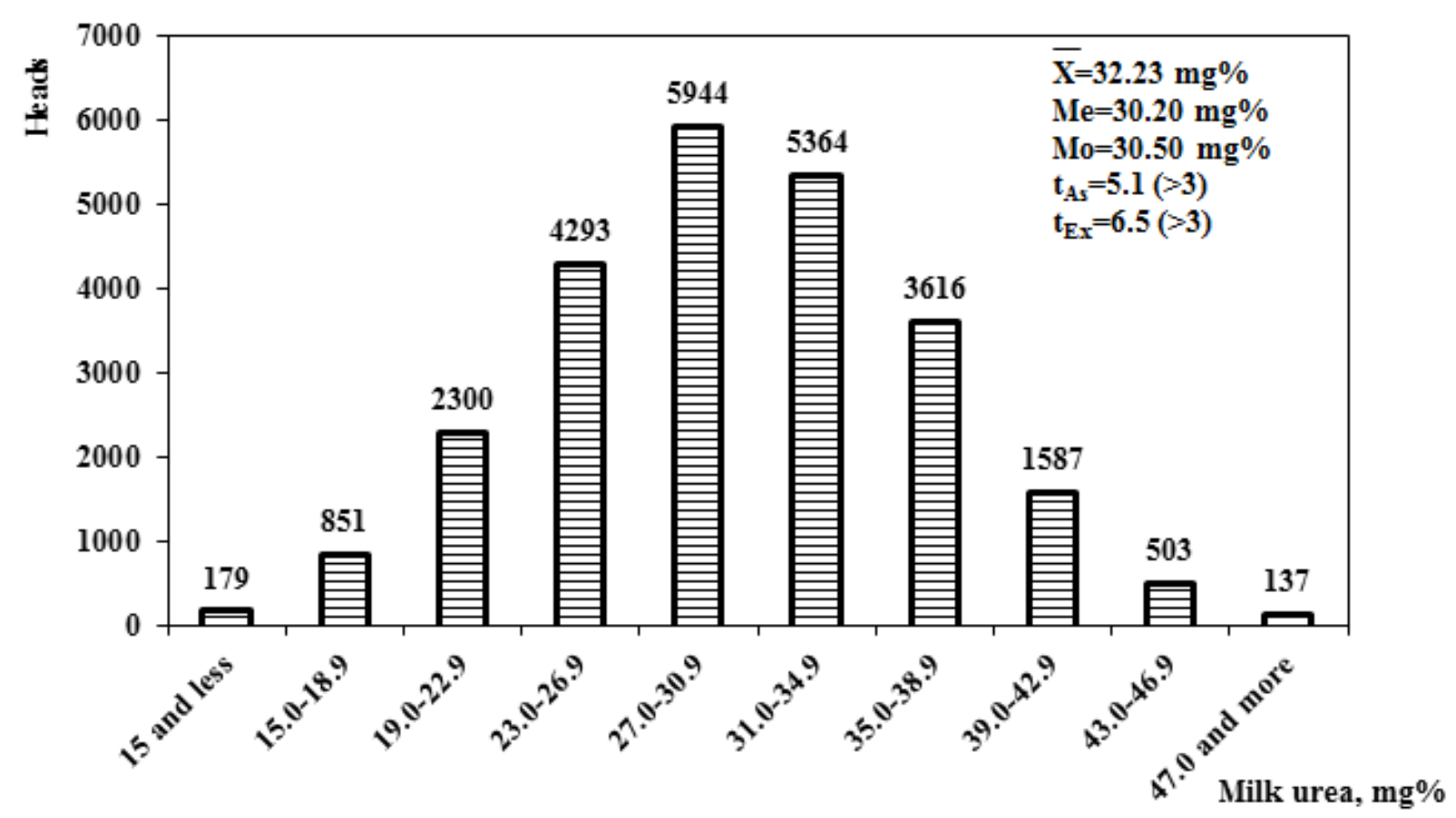

Fig. 1. Distribution of cows by the content of milk urea.

variation statistics, analysis of variance, pair correlation of characteristics and coefficient of heritability were used in the work.

\section{Results and discussion}

It was found that with an average daily milk yield of $25.5 \mathrm{~kg}$, the average content of urea in the analyzed samples was $32.19 \mathrm{mg} \%$, fat $-3.91 \%$, protein $-3.26 \%$. The analysis revealed moderate coefficients of variability (for urea - $18.1 \%$, for fat and protein - 12.2 and $9.2 \%$, respectively). In the studies of K. Rzewuska, T. Strabel (2013), the coefficient of variation of the urea concentration reached $40-41 \%$ [10].

The average content of urea in the analyzed samples is higher than the typical one. Fluctuations ranged from 4.90 to $81.50 \mathrm{mg} \%$. $64.7 \%$ of samples contained high level of urea (more than $30 \mathrm{mg} \%$ ) and $8.4 \%$ of samples contained more than $40 \mathrm{mg} \%$ of urea, which indicates a disturbance in protein metabolism. In our opinion, these disturbances are due to an imbalance in the diet (a high proportion of concentrated feed). It can lead to ketosis, disturbances in reproduction, and early culling of cows, which are often the most productive ones.

Urea level above 30-35 $\mathrm{mg} \%$ indicates excess nitrogen levels in the rumen. An increased content of urea in milk with a decrease in protein occurs when the energy supply of feeding diets is insufficient. The analysis of the diets of the examined cows showed that at high productivity (more than $7600 \mathrm{~kg}$ per lactation), the animals are sufficiently provided with metabolic energy. However, it comes mainly from concentrated feed, which accounts for 48.4 to $64.5 \%$ of the nutritional value of the diet. At the same time, a lack of carbohydrates was noted. The sugar-protein ratio is $0.40-0.47$ (the optimum ratio is $0.8-1.1$ ). For the optimization of protein metabolism, urea level, and for the normal functioning of the gastrointestinal tract, it is necessary to provide the diet with a sufficient amount of carbohydrates.

The calculations showed that the distribution of cows by the content of urea in milk is almost completely consistent with the normal curve $(\bar{X}=32.23 ; \mathrm{Me}=$ 30.20 ; Mo $=30.50 \mathrm{mg} \%$, Fig. 1). It is characterized by positive coefficients of asymmetry $\left(+0.08 ; \mathrm{t}_{\mathrm{As}}=5.1\right)$ and kurtosis $\left(+0.20 ; t_{E x}=6.5\right)$. The curve actually deviates from the null hypothesis. A certain distortion of the normal distribution pattern is probably the result of systematic factors such as metabolic disorders, proteinlactose ratio, and others.

The distribution of cows by fat content $(3.91 ; 3.87$; $3.78 \%)$ and protein $(3.26 ; 3.24 ; 3.08 \%)$ is characterized by a low value of the mode, positive asymmetry coefficients $\left(+0.34\right.$ and +0.50 , respectively, $\left.\mathrm{t}_{\mathrm{As}}>3\right)$ and actually deviates from the null hypothesis. This feature is explained, in our opinion, by a high negative correlation of milk yield with the content of fat and protein in milk, which determines the manifestation of positive asymmetry. The kurtosis coefficients were equal to -0.64 (MF) and +0.47 (MP) $\left(\mathrm{t}_{\mathrm{Ex}}>3\right)$.

Age of cows. An increased content of urea in milk was found in cows of all ages. At the same time, in cows aged 1-2 lactations, the urea content (32.96-32.38 mg\%, Fig. 2) was significantly higher $(P<0.001)$ than in mature animals, and the proportion of milk samples with urea content of more than $40 \mathrm{mg} \%$ was $10.5-9.1 \%$. Further, with age, the number of animals with a high concentration of MU decreased to $7.2-5.4 \%$. This is confirmed by the data of other studies $[3,11]$.

Milk yield. The analysis showed that with an increase in the milk yield of cows, the MP and MF decrease, 


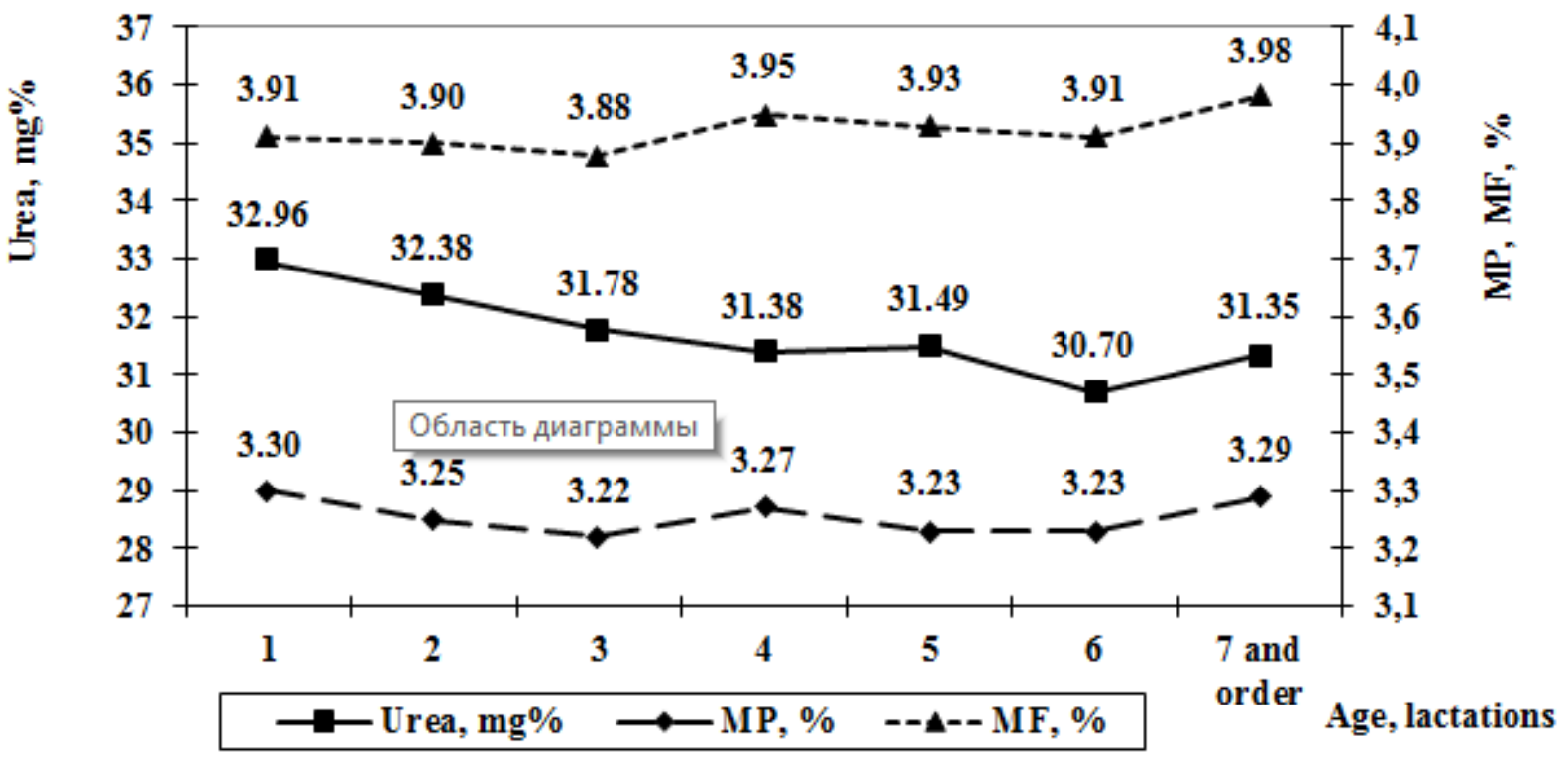

Fig. 2. The content of urea, protein and fat in the milk of cows of different ages.

while the urea content increases (Fig. 3). The maximum MP (3.50\%) and the minimum for MU (31.46 mg\%) were observed in cows with a daily milk yield (DY) of less than $20 \mathrm{~kg}$. In highly productive cows (more than 30 $\mathrm{kg}$ per day, i.e., more than $7000 \mathrm{~kg}$ of milk per lactation), the MP decreases to $3.09-3.02 \%(\mathrm{P}<0.001)$, the MU level rises to $33.56-33.25 \mathrm{mg} \%(\mathrm{P}<0.001)$. According to K. Rzewuska, T. Strabel (2013), the urea content increases from $20.67,21.24$ and up to $23.62 \mathrm{mg} \%$ with DY of less than 20, 20-25 and more than $25 \mathrm{~kg}$, respectively [10]. Highly productive cows produce milk with low levels of fat, protein, and urea nitrogen [1, 3].

Lactation stage. The curve for the urea content actually repeats the curve for the daily milk yield: the maximum level at the peak of lactation and a gradual decrease until the end of lactation (Fig. 4). The most significant exceedance of the norm for MU was observed at the second-third months of lactation (33.46-33.49 $\mathrm{mg} \%$ ). These results coincide with the data of other studies $[1,3,12,13]$, but some authors did not find the connection between the concentration of urea and the stage of lactation, or they detected an increase in the level of urea from the first to the fifth-seventh months [14]. Lactation changes in the level of MU are inverse in relation to the variations in MF and MP, the content of which, starting from the second-third months of lactation, gradually increases to maximum in the last month of lactation.

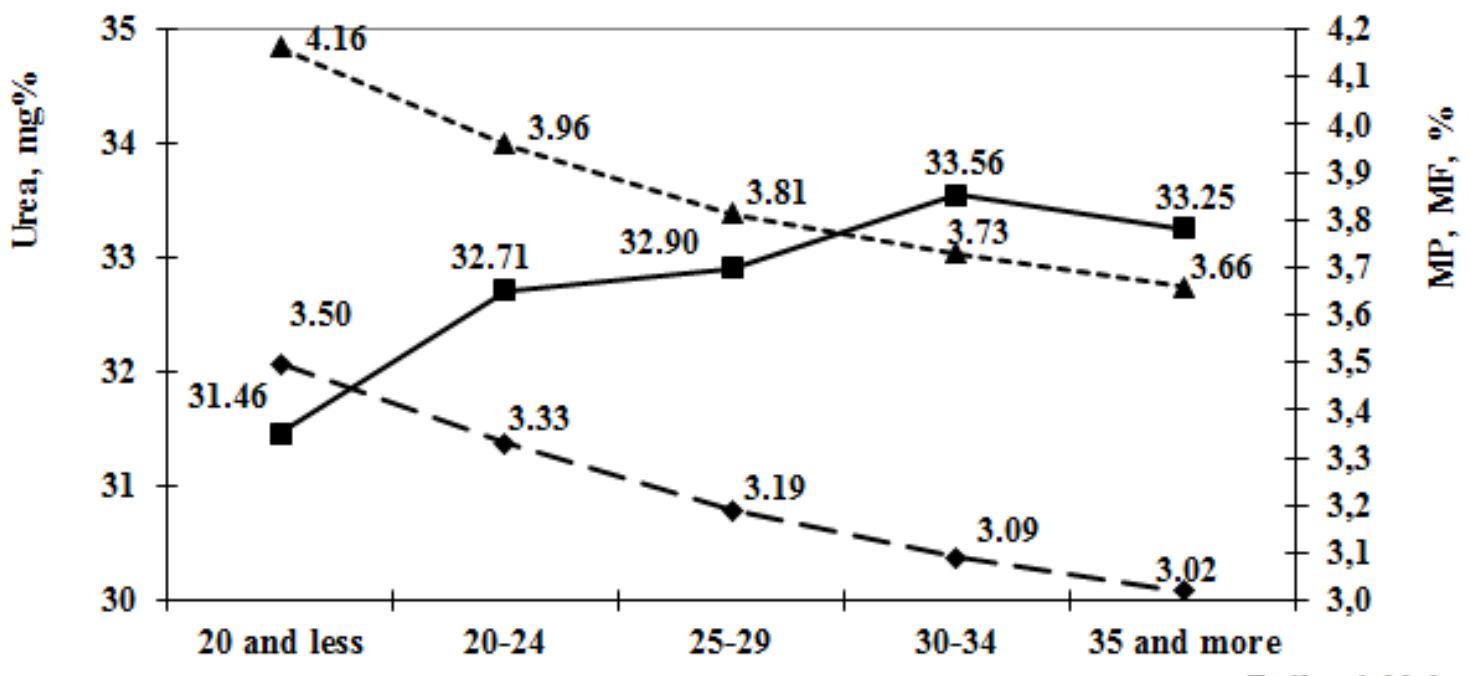

Daily yield, kg

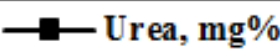

$\longrightarrow \mathrm{MP}, \%$

$--\Delta--M F, \%$

Fig. 3. Content of urea, protein and fat in milk at different daily milk yield (DY). 


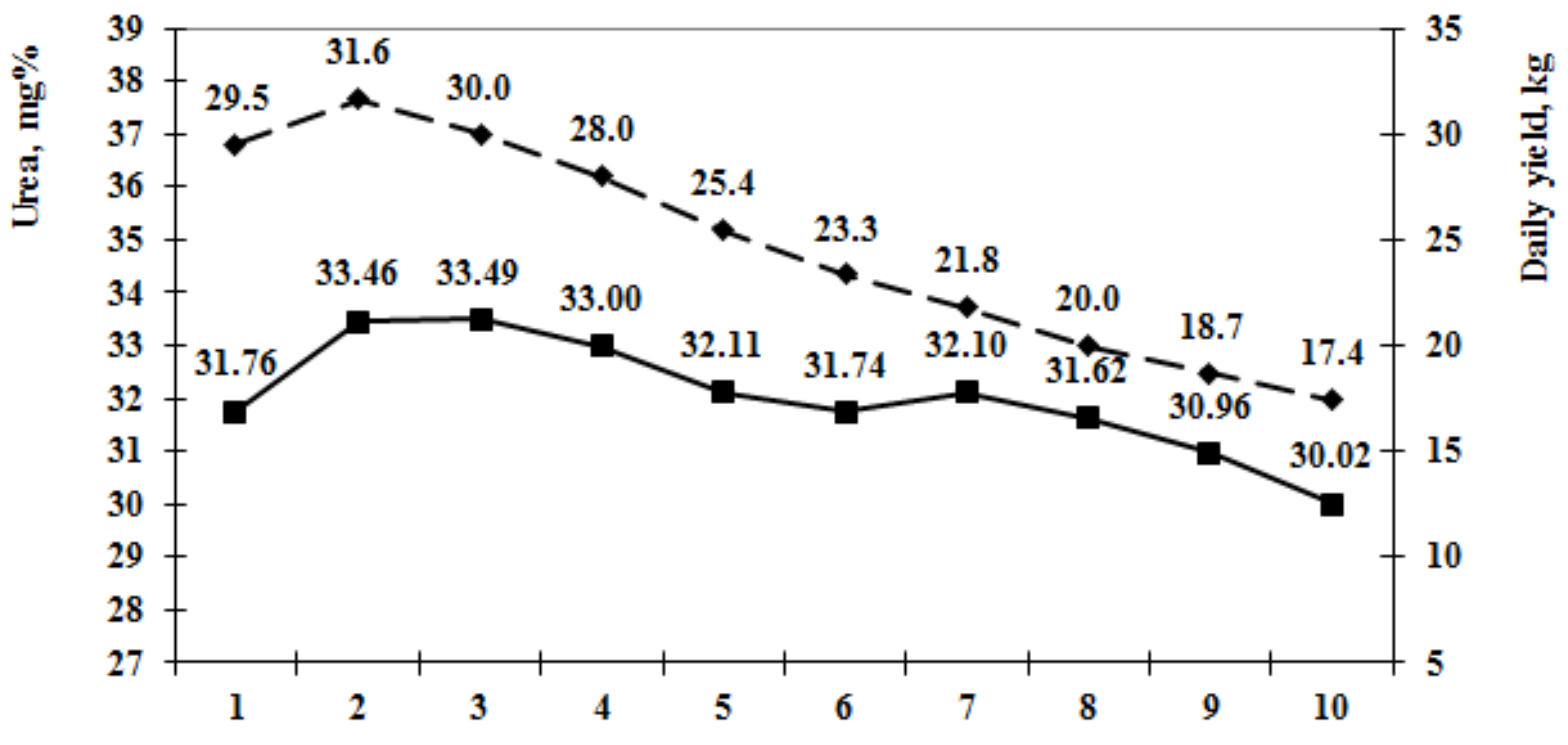

Month of lactation

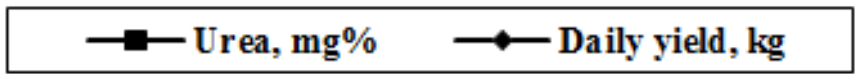

Fig. 4. Changes of urea content and daily milk yield during lactation.

Cows with the same level of productivity but at different stages of lactation did not significantly differ in urea content. Cows with daily milk yield of $25-29 \mathrm{~kg}$ during first stage of lactation had MU of $33.87 \mathrm{mg} \%$, in the middle of lactation $-32.99 \mathrm{mg} \%$, at the end -32.70 $\mathrm{mg} \%$. Cows with a milk yield of $35 \mathrm{~kg}$ per day or more had 33.33-32.97 mg\% of MU. Moreover, it is in the first third of lactation (first stage) that the urea content in milk increases with increasing milk yield.

Season. The study revealed significant differences in the content of urea in milk by seasons. MU varied from $30.51 \mathrm{mg} \%$ in spring to $33.17 \mathrm{mg} \%$ in winter $(\mathrm{P}<0.001)$. Optimal values were observed in August and September (27.83 and $27.03 \mathrm{mg} \%$, respectively), an increased value was in November - $36.66 \mathrm{mg} \%$. The lowest milk yield per month was noted in spring $(24.4 \mathrm{~kg})$, the highest - in summer $(26.4 \mathrm{~kg})$. In autumn MF and MP were higher than in summer and winter. MF was $3.99 \%$ versus 3.87 $3.86 \%$ in summer and in winter, respectively, $\mathrm{P}<0.001$. MP was $3.34 \%$ versus $3.19 \%$ in summer $(\mathrm{P}<0.001)$. The data from other studies about the content of MU by seasons are rather contradictory and are most often explained by ecological or feeding conditions $[3,15,16]$.

Correlation of urea with milk productivity indicators. The study revealed a positive correlation between the MU and DY: $+0.121(\mathrm{P}<0.001)$. It confirms the data presented in Fig. 3. on a significant increase in the level of urea in milk with an increase in daily milk yield up 20 $\mathrm{kg}$ or less to $35 \mathrm{~kg}$ and more. High productive cows get more concentrates. Nitrogen is not absorbed and it excretes to milk in the urea form due to a lack of carbohydrates in the diet. However, some studies [17] revealed a negative correlation between milk urea and daily milk yield (from -0.34 to -0.44 ). Other studies did not find a significant correlation between milk urea and lactation milk yield [18]. The data are given that in highly productive herds the correlation between the concentration of urea and milk yield can be quite high from 0.34 to $0.67-0.79[11,19]$.

Our study revealed a reliable positive correlation of milk urea with lactose $(+0.104)$. This is consistent with other scientific data $[11,15,18]$. Calculations showed a negative correlation between the urea content and the protein content in milk $(-0.287, \mathrm{P}<0.001)$ and non-fat milk solids $(-0.178, \mathrm{P}<0.001)$. The antagonism of $\mathrm{MU}$ and protein is also illustrated by the data presented in Fig. 3. The negative relationship between milk urea and protein is confirmed by other authors [17, 20, 21]. Very small positive correlation was obtained between the content of urea and milk fat $(+0.045, \mathrm{P}<0.001)$. Negative correlation was found between milk urea and dry matter (-0.099) and somatic cells number (-0.079). This indicates lack of connection between these indicators. A typical positive fat-protein correlation was found $(+0.447, \mathrm{P}<0.001)$.

Repeatability and heritability of milk urea. The study revealed a reliable and positive relationship of the MU indicators between adjacent lactations (repeatability coefficients $0.103-0.113, \quad \mathrm{P}<0.01)$. The high repeatability between the first and the third lactations $(+0.427, \quad \mathrm{P}<0.001)$ makes it possible to use MU indicator as a selection trait.

The bull genotype has a significant effect on the amount of milk urea $(\mathrm{P}<0.001)$. The urea level in the daughters of different bulls ranged from $28.69 \mathrm{mg} \%$ to $33.11 \mathrm{mg} \%$. Heritability estimate $\left(\mathrm{h}^{2}\right)$ ranged from 0.222 to $0.367(\mathrm{P}<0.001)$. This indicates that urea concentration in milk can be changed by selection. In addition, the close relationship between milk urea and blood plasma urea may enable early selection of bulls to breed progeny that excrete less urine nitrogen [21]. 


\section{Conclusion}

The study showed that with $25.5 \mathrm{~kg}$ daily milk yield in Ayrshire cows, the urea content was higher than the typical one $-31.19 \mathrm{mg} \%$ with a moderate coefficient of variability of $18.1 \%$. High proportion of concentrated feed in the structure of the annual diet (57\%), a lack of carbohydrates, and a low sugar-protein ratio (0.40-0.47) cause an increased concentration of milk urea and disturbances in protein metabolism. The distribution of cows in terms of urea content in milk is almost completely consistent with the normal curve. The variability of the urea level in milk is due to many factors - the age of cows, lactation period, milk yield, season of the year, connection with other indicators of milk composition. The results obtained can be used to assess the influence of the factors in order to optimize urea content in milk, to correct the diets of cows

\section{References}

1. M. Aguilar, M.D. Hanigan, H.A. Tucker, B.L. Jones, S.K. Garbade, M.L. McGilliard, C.C. Stallings, K.F. Knowlton, R.E. James, J. Dairy Sci., 95 (12), $7261-7268$ (2012)

2. J.W. Spek, J. Dijkstra, G. Van Duinkerken, A. Bannink, J. Agri. Sci., 151, 407-423 (2013)

3. B. Roy, B. Brahma, S. Ghosh, P.K. Pankaj, Asian J. Anim. Vet. Advances., 6, 1-19 (2011)

4. D. Řehák, R. Rajmon, M. Kubešová, M. Štípková, J. Volek, F. Jílek, Czech J. Anim. Sci., 54 (5), 193-200 (2009)

5. K. Čobanović, D. Kučević, M. Plavšić, V. Bogdanović, Mljekarstvo, 67 (4), 267-276 (2017)

6. M. Aguilar, M.D. Hanigan, H.A. Tucker, B.L. Jones, S.K. Garbade, M.L. McGilliard, C.C. Stallings, K.F. Knowlton, R.E. James, J. Dairy Sci., 95 (12), 7261-7268 (2012)

7. A. Shamshidin, D. Aitmukhanbetov, Y. Batyrgaliyev, A. Seitmuratov, J. Anim. Sci., 98 (4), 343 (2020)

8. J.S. Joncer, R.A. Kohn, R.A. Erdman, J. Dairy Sci., 82, 1261-1273 (1999)

9. P. Guliński, E. Salamończyk, K. Młynek, Anim. Sci. Papers and Reports, 34 (1), 5-24 (2016)

10. K. Rzewuska, T. Strabel, J. Appl. Genetics, 54, 473-482 (2013)

11. Maria Cecília Doska, Delma Fabíola Ferreira da Silva, José Augusto Horst, Altair Antônio Valloto, Paulo Rossi Junior, Rodrigo de Almeida, R. Bras. Zootec., 41 (3), 692-697 (2012)

12. Huimin Zhang, Mengqi Wang, Hongrui Jiang, Yan Cui, Hailei Xia, Wei Ni, Mingxun Li, Niel A. Karrow, Zhangping Yang, Yongjiang Mao, Animal Biology, 68 (2), 193-211 (2018)

13. K. Rzewuska, T. Strabel, J. Anim. Feed Sci., 22 (3), 197-203 (2013)
14. M.L. Kgole, C. Visser, C.B. Banga, S. Afr. J. Anim. sci., 42 (5) (2012)

15. Andrés F. Henao-Velásquez, Oscar David Múnera-Bedoya, Ana Cristina Herrera, Jorge H. Agudelo-Trujillo, Mario Fernando Cerón-Muñoz, R. Bras. Zootec., 43 (9) (2014)

16. Chiara Roveglia, Giovanni Niero, Mauro Penasa, Raffaella Finocchiaro, Maurizio Marusi, Nicolas Lopez-Villalobos, Martino Cassandro, Italian J. Anim. Sci., 18 (1), 405-409 (2019)

17. I. Šematovica, L. Liepa, Research for Rural Development, 1, 125-130 (2016)

18. M. Sarker, M. Islam, K. Huque, N. Sarker, M. Hossain, A. Bhuiyan, Bangladesh J. Livestock Research, 19 (1-2), 74-84 (2016)

19. K. Yazgan, J. Makulska, A. Węglarz, E. Ptak, M. Gierdziewicz, Czech J. Anim. Sci., 55, 91-104 (2010)

20. Z. Cao, W. Huang, Y. Wang, W. Wen, M. Ma, S. Li, J. Anim. Vet. Adv., 9, 688-695 (2010)

21. R. Beatson, S. Meier, N.G. Cullen, H. Eding, Animal, 13 (10), 2164-2171 (2019). 